\title{
ANALISIS TINGKAT PERSAINGAN INDUSTRI PERBANKAN DI INDONESIA
}

\author{
Romauli Manurung \\ Fitrawaty \\ Program Studi Ilmu Ekonomi \\ Program Pascasarjana Universitas Negeri Medan \\ Email: ymanroe@rocketmail.com
}

\begin{abstract}
This study aimed to analyze the structure of the banking industry and the level of competition of banking institutions in Indonesia. In measuring and analyzing the model used Panzar-Rosse built on indicators of competition, called H-Stats, which provide a quantitative assessment of the competitive nature of the market. H-statistics calculated from equation reduction in revenue and the size of the total revenue elasticity with respect to changes in input factor prices. Panzar and Rosse show that with certain assumptions, comparison of the static nature of the type of the equation provides a replacement for the overall level of competition prevailing in the market. By using secondary data issued by Bank Indonesia (BI), this study used pooled the data (data panel) is to combine data from year 2010 to 2014 on 9 banking institutions. The results showed that the level of competition in the Indonesian banking industry generally contain the elements of nature and the nature of the market monopoly of perfect competition or are in a situation of monopolistic competition (monopolistic competitions)
\end{abstract}

Key words: Competition, Banking, Panzar-Rosse, Monopoly.

\section{PENDAHULUAN}

eregulasi perbankan pada tahun 1980-an membawa dampak bagi perubahan industri perbankan di Indonesia, terutama dalam struktur pasar dan tingkat persaingan atau kompetisinya. Kebijakan deregulasi tersebut dimulai pada tahun 1983 sampai dengan 1990. Sebelumnya, pembatasan atas operasional perbankan diatur oleh pemerintah. Menurut McLeod (1999), bank-bank pemerintah saat itu bukanlah bank yang bersifat profit oriented melainkan hanya menjadi kepanjangan tangan rezim pemerintah. 
Pasca Kebijakan deregulasi atau liberalisasi diterapkan, sebagian besar kontrol bank sentral terhadap suku bunga dan pemberian kredit mulai dihapuskan, serta memberi kemudahan dalam pendirian kantor cabang, dan mengurangi hambatan masuk pasar. Kebijakan ini selanjutnya meningkatkan persaingan di sektor perbankan. Paket deregulasi selain membawa dampak positif berupa peningkatkan akses jasa bank pada masyarakat juga membawa dampak negatif. Bertambahnya jumlah bank mendorong sektor perbankan lebih agresif dalam pemberian dan penghimpunan dana. Aktivitas perbankan yang meningkat ini menurut Abdullah dan Santoso (2001) tidak disertai dengan penegakan dan pelaksanaan prinsip kehati-hatian, sehingga seringkali pemberian pinjaman tanpa melalui analisis kredit yang baik dan membawa pada NPL (Non-Performing Loan) yang tinggi. Kebijakan deregulasi juga mengubah bentuk struktur industri perbankan, Menurut Rajan (2005) adanya inovasi dalam teknologi juga memberikan andil dalam perubahan tersebut. Sebelumnya deregulasi didasarkan pada kurangnya insentif bagi perbankan untuk melakukan inovasi. Setelah adanya inovasi, perbankan mulai berorientasi kepada produknya. Orientasi terhadap produk perbankan ini disertai dengan insentif promosi seperti pemberian hadiah dan potongan harga makin meningkatkan persaingan di sektor perbankan (Aviliani, 2012). Paket kebijakan yang ditetapkan pada tanggal 1 Juni 1983 (PAKJUN) dengan tujuan memodernisasi perbankan dan kemudian dilanjutkan dengan paket Oktober (PAKTO) pada tanggal 27 Oktober 1988, yang memberi kemudahan perijinan pendirian bank baru, termasuk pembukaan kantor cabang. (Deni dan Djoni, 2004).

Setelah krisis ekonomi tahun 1997-1998, industri perbankan mengalami perubahan drastis dalam jumlah bank. Jika pada tahun 1998 jumlah bank umum mencapai 208, maka pada tahun 2010 jumlah bank umum turun menjadi 120 bank dan terus menurun hingga pada akhir tahun 2014, jumlah bank umum menjadi 119 bank.

Table 1. Perkembangan Jumlah Bank dan Kantor Bank Umum Periode $2010-2014$

\begin{tabular}{lccccc}
\hline \multicolumn{1}{c}{ Jumlah Bank/ Kantor } & $\mathbf{2 0 1 0}$ & $\mathbf{2 0 1 1}$ & $\mathbf{2 0 1 2}$ & $\mathbf{2 0 1 3}$ & $\mathbf{2 0 1 4}$ \\
\hline Jumlah Bank & 120 & 120 & 120 & 120 & 119 \\
\hline Jumlah Kantor & 13.837 & 14.797 & 16.625 & 18.558 & 19.948 \\
\hline
\end{tabular}

Sumber : Statistik Perbankan Indonesia, Bank Indonesia 
Tabel 1 di atas, menjelaskan perkembangan jumlah bank umum yang relatif stabil sebanyak 120 bank di tahun 2010 hingga akhir tahun 2014 jumlah bank menjadi 119 bank. Namun di sisi lain, jumlah kantor bank dari tahun 2010 hingga tahun 2014 meningkat signifikan seiring dengan kebutuhan akan pentingnya pelayanan kepada masyarakat khususnya di sektor keuangan. Tercatat di tahun 2010 jumlah kantor perbankan sebanyak 13.837 unit, menjadi sebanyak 14.797 unit di tahun 2011. Peningkatan jumlah kantor lembaga perbankan juga terjadi di tahun 2012 sebanyak 16.625 unit, tahun 2013 sebanyak 18.558 unit dan tahun 2014 sebanyak 19.948 unit.

Peningkatan jumlah bank beserta unit pelaksananya berpotensi mendorong bisnis sektor perbankan menjadi lebih kompetitif dan meningkatkan efisiensi dan kesehatan perbankan. Namun untuk perbankan Indonesia, sebagian besar bank-bank swasta pada masa sebelum krisis dimilikioleh parausahawan besar; akibatnya, saat usahanya membutuhkan pendanaan besar, mereka cenderung memobilisasi dana masyarakat melalui banknya untuk kepentingan usahanya (kelompok/grupnya). Ini berati tujuan penerbitan Pakto 88 yang awalnya bertujuan untuk mengalirkan dana masyarakat kepada masyarakat, bergeser menjadi penyaluran kepada grupnya sehingga muncul potensi pelanggaran Batas Maksimum Pemberian Kredit (BMPK), (Deni dan Djoni, 2004). Kondisi ini melemahkan infrastruktur industri perbankan, akibatnya ketika pasar keuangan internasional bergejolak, yang dimulai dengan krisis nilai tukar mata uang dinegara-negara Asia, perbankan Indonesia tidak mampu bertahan. Kondisi ini mengakibatkan meningkatnya krisis kepercayaan terhadap rupiah dan perbankan nasional, terutama setelahadanya pencabutan ijin usaha 16 bank pada bulan November 1997.

Beberapa tahun selanjutnya, Bank Indonesia menerbitkan Arsitektur Perbankan Indonesia (API) sebagai kerangka dasar sistem perbankan Indonesia yang bersifat menyeluruh. API diharapkan dapat memberikan arah, bentuk, dan tatanan industri perbankan untuk rentang waktu lima sampai sepuluh tahun ke depan (BI, 2007, Arsitektur Perbankan Indonesia).

Cetorelli (2001) manyatakan bahwa ada pandangan lama mengatakan bahwa kompetisi perbankan akan mendorong ke situasi pasar yang lebih baik. Kompetisi Industri Perbankan Indonesia setelah kemunculan API, yang didukung oleh penguatan struktur permodalan bank-bank, 
diharapkan perbankan Indonesia menjadi lebih stabil dan mampu berfungsi sebagai lembaga intermediasi. Kestabilan akan menghasilkan perbankan nasional yang lebih kuat danpada akhirnya mampu bersaing dengan perbankan asing di pasar internasional.

Menurut Mulyaningsih dan Daly (2011) menilai Arsitektur Perbankan Indonesia (API) telah mempengaruhi struktur dan tingkat kompetisi perbankan di Inonesia secara langsung melalui dua kebijakan Bank Indonesia yaitu jumlah modal minimum dan kebijakan kepemilikan tunggal. Kebijakan ini menyebabkan meningkatnya skala ekonomi bank yang melakukan konsolidasi khususnya bank-bank kecil dan menengah dan meningkatnya distribusi pangsa pasar sehingga meningkatkan kompetisi. Sedangkan untuk bank-bank besar memiliki kekuatan monopolis sehingga pasar menjadi kurang kompetitif. Kondisi ini akan mempengaruhi kinerja bank-bank besar, menengah dan kecil.

Profit yang dihasilkan oleh industri perbankan merupakan salah satu indikator yang digunakan untuk menentukan kinerja bank. Berdasarkan pada hipotesis Stucture-Conduct-Performance (SCP) menyatakan bahwa struktur industri akan menentukan bagaimana industri berperilaku sehingga dari struktur dan perilaku tersebut akan menentukan kinerja industri. Pendekatan SCP pada awalnya dikemukakan oleh Bain (1951), yang meneliti apakah tingginya konsentrasi dalam pasar merupakan kolusi dan praktek non kompetisi lain diantara perusahaan yang besar.

Disamping itu kinerja perbankan menurut Sofyan (2002), dapat diukur dengan menggunakan rata-rata tingkat bunga pinjaman, rata-rata tingkat bunga simpanan, dan profitabilitas perbankan. Dalam penelitiannya menyatakan bahwa tingkat bunga simpanan merupakan ukuran kinerja yang lemah dan menimbulkan masalah, sehingga dalam penelitiannya disimpulkan bahwa profitabilitas merupakan indikator yang paling tepat untuk mengukur kinerja suatu bank. Ukuran profitabilitas yang digunakan adalah Return on Asset (ROA) pada industri perbankan. ROA memfokuskan kemampuan perusahaan untuk memperoleh earning dalam operasi perusahaan. Beberapa faktor yang bepengaruh terhadap kinerja bank adalah CAR, BOPO, NIM, dan LDR.

Perkembangan perbankan setelah tahun 2010 menunjukkan kinerja yang membaik sejalan dengan perkembangan kondisi ekonomi makro di 
Indonesia. Di sisi lain, sektor perbankan mempertahankan marjin yang besar untuk memperoleh profit atau laba super normal terlihat dari data yang tersaji di Tabel 1.2 yang menunjukkan nilai Net Interest Margin (NIM) yang masih tinggi yaitu di atas 5\% bahkan tertinggi dibandingkan NIM negara lain di kawasan ASIA. Menurut Darmin Nasution nilai NIM yang ideal berkisar antara 3\% - 5\%. Hal ini menunjukkan bahwa perbankan Indonesia sebagai entitas bisnis berusaha mempertahankan tingginya spread suku bunga kredit dengan suku bunga simpanan sebagai strategi perilaku maksimisasi laba.

Ketika perbankan Indonesia berada dalam struktur pasar yang tidak kompetitif (imperfect competition), maka bank-bank umum nasional tidak akan terpacu untuk meningkatkan efisiensi. Inefisiensi di industri perbankan tercermin dari tingginya rasio perbandingan antara biaya operasional dengan pendapatan operasional.

Jika dianalisis lebih terinci jumlah bank yang tercatat dan terdaftar pada Bank Indonesia pada tahun 2014 sebanyak 119 lembaga perbankan dan hanya 9 bank yang tercatat memiliki daya saing yang tinggi. Hal ini ditunjukkan dengan aset yang dimiliki oleh ke-9 lembaga perbankan tersebut. Besarnya jumlah aset yang dimiliki ke-9 lembaga perbankan tersebut disajikan dalam Grafik 1 berikut

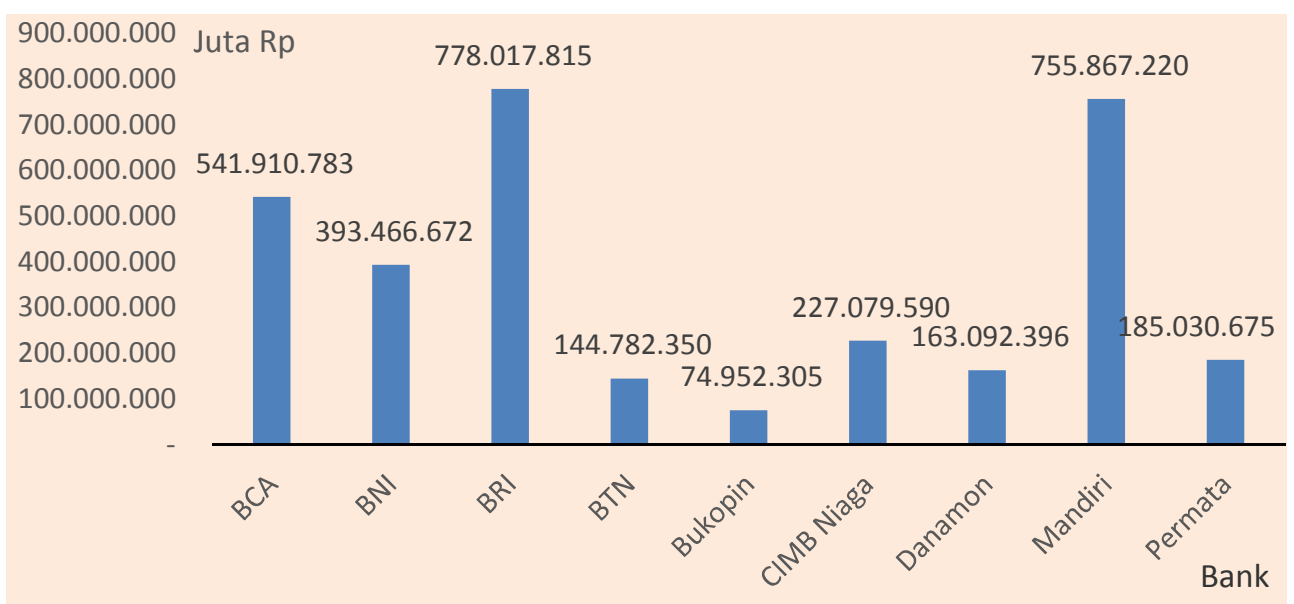

Sumber : Statistik Perbankan Indonesia, Bank Indonesia (diolah)

Gambar 1. Jumlah Aset 9 Lembaga Perbankan Terbesar Tahun 2014

Gambar 1 menunjukkan jumlah aset yang dimiliki 9 perusahaan perbankan terbesar selama tahun 2014, dimana lembaga perbankan yang memiliki aset

QE Journal | Vol.05 - No. 03 September 2016 - 153 
terbesar adalah BRI sebesar Rp. 778.017.815 juta, disusul oleh Bank Mandiri dengan nilai aset sebesar Rp. 755.867.220 juta dan BCA dengan nilai aset sebesar Rp. 541.910 .783 juta. Dari ke-9 lembaga perbankan tersebut, yang memiliki aset terendah adalah Bukopin sebesar Rp. 74.952 .305 juta disusul oleh BTN sebesar Rp. 144.782.350 juta dan Danamon sebesar Rp. 163.092.396 juta.

Sebagai suatu industri, analisis perilaku individual bank tidak terlepas dari struktur pasar di mana bank beroperasi. Memperhatikan persaingan antar pelaku usaha yang bertambah ketat dan tidak sempurna (imperfect competition), maka nilai-nilai persaingan usaha yang sehat perlu mendapat perhatian lebih besar dalam sistem ekonomi maupun perbankan Indonesia. Penegakan hukum persaingan merupakan instrumen ekonomi yang sering digunakan untuk memastikan bahwa persaingan antar pelaku usaha berlangsung dengan sehat dan hasilnya dapat terukur berupa peningkatan kesejahteraan masyarakat. Dalam kondisi pasar yang bersaing tidak sempurna, pelaku usaha secara individual atau melalui concerted action dapat menetapkan harga dan alokasi sumber daya ekonomi. Oleh karenanya, para ahli ekonomi industri telah menemukan sebuah dalil ekonomi yang menggambarkan hubungan (korelasi) antara structure (S), conduct $(\mathrm{C})$, dan performance $(\mathrm{P})$.

Pada awalnya, organisasi industri diatur dengan sebuah paradigma yang mengatakan adanya hubungan searah antara structure, conduct and performance (SCP). Sebuah hubungan yang menggambarkan bahwa struktur (S) sebuah industri/sektor akan mempengaruhi perilaku (C), yang pada gilirannya akan menghasilkan kinerja $(\mathrm{P})$ industri/sektor tersebut. Kinerja industri dapat berupa pertumbuhan industri, efsiensi, inovasi, deviden, profitabilitas, tingkat kepuasan konsumen dan sebagainya yang merupakan bagian dari kesejahteraan masyarakat

Para ahli ekonomi perbankan menjelaskan bahwa ada tiga pemikiran dalam menganalisis hubungan antara struktur pasar dan kinerja dengan menggunakan paradigma Structure Conduct Performance (SCP). Pertama, dikenal sebagai hipotesis tradisional yang mendasarkan pada preposisi yang menyatakan bahwa konsentrasi pasar akan mendorong kolusi di antara perusahaan-perusahaan pada suatu industri yang selanjutnya akan meningkatkan profit. Kedua, hipotesis diferensiasi yang mendasarkan pada preposisi yang menyatakan bahwa pangsa pasar yang diperoleh adalah 
akibat perilaku diferensiasi produk yang dilakukan dan yang ketiga, hipotesis efisiensi yang mendasarkan pada preposisi yang menyatakan bahwa efisiensi akan meningkatkan pangsa pasar dan pada akhirnya akan meningkatkan konsentrasi pasar juga, namun peningkatan pangsa pasar dan konsentrasi ini merupakan akibat dari perilaku yang efisien sehingga akan meningkatkan profit atau keuntungan.

Salah satu proksi untuk mengukur kinerja sebuah perusahaan atau industri adalah profit yang dihasilkan oleh perusahaan atau industri tersebut. Secara umum, profitabilitas dapat mempengaruhi dan dipengaruhi oleh struktur pasar, perilaku pasar, maupun proksi lain dari kinerja pasar. Secara khusus profitabilitas dapat dipengaruhi oleh kolusi yang terjadi dalam sebuah industri, diferensiasi produk yang dilakukan, dan efisiensi perusahaan.

Pandangan Efficiency Hypothesis memberikan interpretasi yang berbeda mengenai hubungan antara keuntungan, kinerja, dan konsentrasi yang disebutkan oleh pandangan SCP tradisional. Pandangan ini mengatakan bahwa tingginya tingkat keuntungan tidak selalu menandakan kinerja pasar yang rendah, karena sebuah perusahaan yang efisien dapat menarik konsumen tanpa harus dengan menetapkan tingkat harga yang tinggi yang akan merugikan konsumen dan dapat menjadi barriers to entry bagi pesaing baru. Sehingga menurut pandangan ini, pangsa pasar dan konsentrasi bukan merupakan proksi dari kekuasaan pasar tetapi merupakan proksi dari efisiensi perusahaan, sehingga konsentrasi tinggi tidak identik dengan kolusi. Dimana perusahaan yang efisien akan bisa mendapatkan pangsa pasar yang besar, sehingga pada akhirnya struktur pasarnya juga akan cenderung terkonsentrasi.

Struktur perbankan di Indonesia menurut undang-undang, terdiri atas bank umum dan BPR. Perbedaan utama bank umum dan BPR adalah dalam hal kegiatan operasionalnya. BPR tidak dapat menciptakan uang giral, dan memiliki jangkauan dan kegiatan operasional yang terbatas. Selanjutnya, dalam kegiatan usahanya dianut dual bank system, yaitu bank umum dapat melaksanakan kegiatan usaha bank konvensional dan atau berdasarkan prinsip syariah. Pemilihan bank umum menjadi objek penelitian dinilai relevan, karena bank umum sebagai bagian industri perbankan Indonesia memiliki struktur pasar yang sangat terkonsentrasi dengan peran bank pemerintah sebagai price leader. Oleh karena itu, besar

QE Journal | Vol.05 - No. 03 September 2016 - 155 
kemungkinan struktur industri perbankan Indonesia cenderung mengarah pada aktivitas yang bersifat kolusif dan menjauhi titik kondusif.

Industri perbankan mempunyai karakteristik tertentu yang sangat berbeda dengan industri lainnya, diperlukan regulasi dan undang-undang yang jelas untuk dapat mengaturnya agar berjalan sesuai dengan sasaran utamanya yaitu menuju perbankan yang sehat. Persaingan usaha yang terlalu ketat (overcompetition) dalam industri perbankan akan memaksa bank untuk mengambil resiko lebih tinggi (excessiverisk) terutama dalam persaingan pasar kredit dan deposito. (Ariyanto, 2004).

Persaingan industri perbankan adalah penting, hal ini dikarenakan segala macam bentuk kegagalan pasar dan perilaku anti persaingan akan memberikan pengaruh yang cukup besar terhadap efisiensi produksi, kesejahteraan masyarakat (consumer welfare) dan pertumbuhan ekonomi. Penelitian yang berkaitan dengan struktur pasar perbankan dan penyebarannya telah banyak dilakukan di beberapa negara seperti penelitian yang dilakukan oleh Mamatzkis et al. (2005) di Eropa, Hondroyiannis et al. (1999) di Yunani, Bikker dan Haaf (2002) di 23 Negara maju, dan lain-lain. Hasil penelitian akan berbeda tergantung pada kondisi pasar yang ada di masing-masing tempat atau negara tersebut.

Secara teoritis, analisa yang digunakan untuk mengukur tingkat persaingan industri sektor keuangan khususnya dalam sektor perbankan dapat digunakan dua macam pendekatan. Pertama, dengan menggunakan pendekatan yang dikembangkan oleh Iwata (1974), Bresnahan (1982) dan Lau (1982). Kedua, pendekatan yang dikembangkan oleh Panzar dan Rosse (1987). Model ini memiliki penjelasan penting yang sama, mereka mengukur persaingan dengan memperkirakan penyimpangan dari harga yang kompetitif. (Claessens dan Laeven, 2004).

Model Iwata terdiri atas estimasi nilai varians untuk perusahaan milik perseorangan yang memasok barang sejenis dalam pasar oligopoly. Model Bresnahan-Lau membahas estimasi sistem persamaan simultan dimana parameter yang mewakili tingkat kekuatan pasar perusahaan disertakan. Kedua model Iwata dan Bresnahan-Lau akan diterapkan untuk tujuan yang empiris. Model Panzar-Rosse dibangun berdasarkan indikator kompetisi, yang disebut H-Statistik, yang memberikan penilaian kuantitatif terhadap sifat kompetitif pasar. H-Statistik dihitung dari persamaan 
pengurangan pendapatan dan ukuran yang elastisitas dari total pendapatan sehubungan dengan perubahan faktor input harga. Panzar dan Rosse menunjukkan bahwa dengan asumsi tertentu, perbandingan sifat statis dari jenis persamaan tersebut menyediakan pengganti untuk keseluruhan tingkat persaingan yang berlaku di pasar.

Penelitian ini bertujuan (1) untuk menganalisis struktur industri perbankan dan tingkat persaingan lembaga perbankan di Indonesia dan (2) mengetahui dan menganalisis pengaruh EQTA, LOATA, LFTA, LDTLD, PL dan PCE terhadap NITA pada lembaga perbankan di Indonesia.

\section{METODE PENELITIAN}

Penelitian ini akan menganalisis tingkat persaingan yang terjadi pada industri perbankan nasional. Objek dari penelitian ini adalah perbankan nasional, terutama perbankan yang memiliki kontribusi dominan dalam industri perbankan nasional. Penelitian yang dilakukan digolongkan ke dalam jenis penelitian penjelasan atau explanatory research, yang fokus penelitiannya menjelaskan hubungan variabel-variabel independen terhadap variabel dependen. Selanjutnya, dalam penelitian ini dilakukan analisis kuantitatif yang terdiri atas perumusan masalah, menyusun model, proses mendapatkan data, mencari solusi, menguji solusi, menganalisis hasil dan mengimplementasikan hasil (mudrajad, 2007).

Penelitian ini menggunakan data sekunder yang dikeluarkan oleh Bank Indonesia (BI) dalam beberapa publikasi. Penelitian ini menggunakan pooled data (data panel) yaitu dengan menggabungkan data tahun 2010$2014(\mathrm{~N}=5)$ atas 9 lembaga perbankan nasional $(\mathrm{T}=9)$. Maka banyaknya data adalah $\mathrm{N} \times \mathrm{T}=5 \times 9$ sama dengan 45. Dalam mengukur dan menganalisis data digunakan model Panzar-Rosse yang dibangun berdasarkan indikator kompetisi, yang disebut H-Statistik yang memberikan penilaian kuantitatif terhadap sifat kompetitif pasar. HStatistik dihitung dari persamaan pengurangan pendapatan dan ukuran yang elastisitas dari total pendapatan sehubungan dengan perubahan faktor input harga.

\section{HASIL DAN PEMBAHASAN}

Untuk mengetahui tingkat persaingan industri perbankan di Indonesia sebelumnya dilakukan regresi berganda dengan menggunakan metode 
panel data yang menggabungkan antara data cross section yaitu data 9 bank umum terbesar dengan data time series yaitu data tahunan dari tahun 2010 hingga tahun 2014.

Tabel 2. Hasil Estimasi Common Efek Model

\begin{tabular}{|c|c|c|c|c|}
\hline Variable & Coefficient & Std. Error & t-Statistic & Prob. \\
\hline 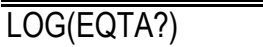 & 0.003530 & 0.217947 & 0.016195 & 0.9872 \\
\hline LOG(LOATA?) & -2.120271 & 0.483369 & -4.386446 & 0.0001 \\
\hline LOG(LFTA?) & 2.613076 & 0.650947 & 4.014270 & 0.0003 \\
\hline LOG(LDTLD?) & 2.593879 & 0.337158 & 7.693368 & 0.0000 \\
\hline LOG(PL?) & 0.266866 & 0.193077 & 1.382174 & 0.1748 \\
\hline LOG(PCE?) & -0.313268 & 0.170801 & -1.834112 & 0.0743 \\
\hline & \multicolumn{4}{|c|}{ Weighted Statistics } \\
\hline R-squared & 0.902866 & \multicolumn{2}{|c|}{ " Mean dependent var } & -7.873097 \\
\hline Adjusted R-squared & 0.890413 & \multirow{2}{*}{\multicolumn{2}{|c|}{$\begin{array}{l}\text { S.D. dependent var } \\
\text { Sum squared resid }\end{array}$}} & 7.079112 \\
\hline S.E. of regression & 0.319638 & & & 3.984567 \\
\hline Durbin-Watson stat & 0.978352 & & & \\
\hline
\end{tabular}

Sumber : Diolah Dengan EV iews 6,0

Hasil estimasi menunjukkan bahwa nilai probability $\mathrm{F}$ hitung uji Chow (Chow Test) $=0,0000<\alpha=0,05$ yang berarti model yang cocok digunakan pada analisis ini adalah model OLS atau common effect. Hal ini juga diperkuat dengan hasil estimasi model, dimana pengaruh arah antara variabel independen dengan variabel dependen yang lebih banyak sesuai dengan teori dan penelitian sebelumnya adalah dengan model OLS atau common effect, sehingga diputuskan untuk estimasi model NITA selanjutnya akan menggunakan model common effect.

\section{Uji Parsial (t-test)}

Uji parsial juga disebut uji tingkat-penting (test of significance). Hasil estimasi masing-masing variabel sebagai berikut:

a. Nilai t-hitung EQTA sama dengan 0.016195 dengan nilai probabilita $t$ sebesar 0.9872 yang berarti variabel EQTA berpengaruh secara positif namun tidak signifikan terhadap NITA pada tingkat kepercayaan 90 persen.

b. Nilai t-hitung LOATA sama dengan -4.386446 dengan nilai probabilita $\mathrm{t}$ sebesar 0.0001 yang berarti variabel LOATA berpengaruh negatif dan signifikan terhadap variabel NITA dengan tingkat kepercayaan 90 persen. 
c. Nilai t-hitung LFTA sama dengan 4.014270 dengan nilai probabilita $t$ sebesar 0.0003 yang berarti variabel LFTA berpengaruh positif dan signifikan terhadap variabel NITA dengan tingkat kepercayaan 90 persen.

d. Nilai t-hitung LDTLD sama dengan 7.693368 dengan nilai probabilita $t$ sebesar 0.0000 yang berarti variabel LDTLD berpengaruh positif dan signifikan terhadap variabel NITA dengan tingkat kepercayaan 90 persen

e. Nilai t-hitung PL sama dengan 1.382174 dengan nilai probabilita $t$ sebesar 0.1748 yang berarti variabel PL berpengaruh positif namun tidak signifikan terhadap variabel NITA dengan tingkat kepercayaan 90 persen.

f. Nilai t-hitung PCE sama dengan -1.834112 dengan nilai probabilita $t$ sebesar 0.0743 yang berarti variabel PCE berpengaruh negatif dan signifikan terhadap variabel NITA dengan tingkat kepercayaan 90 persen.

\section{Uji Serempak (F-statistik)}

Model yang digunakan adalah OLS model common effect, sehingga untuk uji F statistik tidak dibutuhkan dalam penelitian ini. Uji dilanjutkan dengan uji lainnya yang sesuai dengan model penelitian ini.

\section{Uji Keofisien Determinasi $\left(\mathbf{R}^{2}\right)$}

$\mathrm{R}^{2}$ terletak antara 0 dan $1 . \mathrm{R}^{2}$ sama dengan 1 , berarti variabel-variabel bebas menjelaskan 100 persen variasi variabel terikat. Sebaliknya, $R^{2}$ sama dengan 0 , berarti variabel-variabel bebas dalam model tidak menjelaskan sedikitpun variasi variabel terikat. Model dikatakan lebih baik kalau $\mathrm{R}^{2}$ semakin dekat dengan 1 (Gujarati: 2003). Estimasi model menghasilkan $\mathrm{R}^{2}$ sebesar 0,902866. Artinya, keberadaan variabel-variabel bebas (EQTA, LOATA, LFTA, LDTLD, PL dan PCE) mampu menjelaskan variabel terikat (NITA) sebesar 90,29 persen, selebihnya yang 9,71 persen dijelaskan oleh variabel-variabel lain diluar model. Dengan $R^{2}$ 0,9029, maka hasil estimasi memenuhi uji kesesuaian dari aspek koefisien determinasi. Hasil estimasi layak dianalisis. 


\section{Analisis Tingkat Persaingan Industri Perbankan di Indonesia}

Dalam mengukur tingkat persaingan industri perbankan di Indonesia diukur berdasarkan kesepakatan umum tentang input yang digunakan oleh perusahaan perbankan, yaitu tenaga kerja, dana pinjaman (terdiri giro dan deposito berjangka) dan modal fisik (modal tetap), yang sejalan dengan proses produksi yang diselenggarakan oleh Sealey dan Lindley (1977). Sehingga persamaan umum untuk mempeeroleh H-statistik adalah:

$$
|\mathrm{Ht}|=\beta_{1 \mathrm{t}}+\beta_{2 \mathrm{t}}+\beta_{3 \mathrm{t}}
$$

Sehingga diperoleh H-statistik sebesar : 0,266866 - 0,313268 +0,003530 = 0,042872 , dimana nilai ini terletak antara $0<\mathrm{H}<1$. Menurut Hendroyiannis (1999) nilai $\mathrm{H}$ statistik yang lebih besar dari 0 dan lebih kecil dari 1 menunjukkan bahwa tingkat persaingan industri perbankan di Indonesia secara umum mengandung unsur-unsur sifat pasar monopoli dan sifat pasar persaingan sempurna atau berada dalam situasi kompetisi monopolistic (Monopolistic Compotition).

Hasil penelitian ini sejalan dengan penelitian yang telah dilakukan oleh Claessens dan Laeven (2003) yang juga menyimpulkan hasil yang sama bahwa perbankan di Indonesia masuk pasar monopolistik. Penelitian ini akhirnya menguatkan penelitian-penelitian sebelumnya yang telah dilakukan oleh Nathan dan Neave $(1989)$ dan Shaffer $(1985,1993)$ dalam Hondroyiannis (1999) yang menyatakan bahwa perbankan akan mampu dan memperoleh pendapatannya jika sistem pasar yang ada mempunyai karakter pasar monopolistik. Juga dalam Hondroyiannis (1999), Molyneux et al. yang menyebutkan bahwa bank-bank yang ada di Jerman, Inggris, Perancis dan Spanyol memperoleh pendapatannya dalam kondisi pasar perbankan pada kondisi persaingan monopolistik.

Hasil estimasi yang ditunjukkan dalam model $H$-stat diperoleh bahwa jika harga input mengalami kenaikan, maka pendapatan perbankan juga akan mengalami peningkatan. Hal ini berangkat dari asumsi bahwa kenaikan biaya input muncul sebagai akibat dari semakin banyaknya jumlah pelayanan jasa dan output perbankan yang diberikan sehingga pada akhirnya dapat meningkatkan pendapatan perbankan.

Dari hasil estimasi dan pembahasan serta analisa yang dilakukan maka hipotesa yang diajukan pada Bab II yang menyatakan bahwa pasar 
perbankan di Indonesia merupakan pasar persaingan monopolistik (monopolistic competition) sudah tepat dan terbukti secara empiris.

\section{KESIMPULAN}

1. Dari hasil estimasi menunjukkan bahwa tingkat persaingan industri perbankan di Indonesia secara umum berada dalam situasi kompetisi monopolistik (Monopolistic Compotition).

2. Model yang digunakan mampu untuk menjelaskan variabel pendapatan (NITA), dimana variabel LFTA dan LDTLD berpengaruh positif dan signifikan, variabel LOATA dan PCE berpengaruh negatif dan signifikan namun variabel EQTA dan PL tidak berpengaruh signifikan terhadap NITA pada lembaga perbankan di Indonesia.

3. Kenaikan harga input (dana, modal dan tenaga kerja), yang digunakan untuk menghasilkan output bank berdampak terhadap peningkatan pendapatan yang akan diterima oleh perbankan. Ini sesuai dengan asumsi bahwa semakin tinggi harga input berarti semakin tinggi pula biaya input bank sebagai dampak semakin banyaknya permintaan output bank yang pada akhirnya meningkatkan pendapatan bank.

4. Model PR yang digunakan untuk mengukur tingkat persaingan di sektor perbankan menunjukkan bahwa perbankan di Indonesia pada tahun 2010-2014 masuk ke dalam pasar persaingan monopolistik.

\section{Saran}

1. Diharapkan peran pemerintah dalam hal ini BI sebagai lembaga otoritas moneter lebih memperketat dan memperkuat kebijakankebijakan moneter dalam bentuk regulasi yang dapat dijadikan acuan dalam operasional perusahaan. Memberikan sanksi yang tegas berupa penggabungan (merger) hingga penutupan operasional perbankan bagi bank-bank bermasalah dan tidak sehat. Pengawasan dan pemantauan secara intensif dan simultan terhadap bank-bank yang dianggap akan memberikan dampak negatif pada lembaga perbankan lainnya, memberikan stimulus dan reward pada bank-bank yang patuh pada aturan yang ditetapkan serta memberikan kemudahan dan keringanan dalam mengeluarkan program-program bank yang baru untuk meningkatkan laba perusahaan itu sendiri. 
2. Diharapkan adanya penelitian-penelitian sejenis yang dilakukan secara terus-menerus karena perkembangan di sektor perbankan sangatlah dinamis, sehingga diperlukan penelitian dengan data-data terbaru dan juga sampel yang lebih besar.

3. Diharapkan dari hasil penelitian adalah kesimpulan mengenai struktur pasar perbankan di Indonesia sehingga diperlukan penelitian lebih lanjut mengenai implikasi struktur perbankan terhadap kebijakan yang dilakukan oleh Bank Indonesia (otoritas moneter) untuk menjaga kestabilan sektor keuangan dan moneter.

\section{DAFTAR PUSTAKA}

Abdullah, B dan W. Santoso, 2001, The Indonesian Bangking Industry : Compotition, Consolidation and systemic Stability, BIS Paper No. 4.

Ariyanto, Taufik, 2004, Profil Persaingan Usaha Dalam Industri Perbankan Indonesia, Komisi Pengawas Persaingan Usaha (KPPU), Jakarta.

Aviliani, 2012, Segmentasi Nasabah Tabungan Mikro Berdasarkan Recency, Frequency dan Monetary : Kasus Bank BrI, Finance and Banking Journal, Vol. 13 No. 1

Bain, Joe E, 1951, Relation of Profit Rate to Industry Compotition : American Manufacturing, 1936-1950, The Quartely of Economic, 65 hsl.

Bikker, Jakob A. dan Haaf, Katharina. 2002. Competiton, Concentration and Their Relationship: An Empirical Analysis of The Banking Industry. Journal of Banking \& Finance 26 (2002) 21912214.

Cetorelli, Nicholson, 2001, Competition Among Banks: Good or Bad?, Economic Perspective Federal Reserve Bank of Chicago.

Claessen, S dan Laeven, L., 2004,What Drives Bank Competition: Some International Evidence. Journal of Money, Credit, and Banking.

Claessens, Stijn dan Laeven, Luc. 2003. What Drive Bank Competition? Some International Evidence. World Bank Policy Research: Working Paper 3113.

Deni, Daruri A dan Djoni, Edward, 2004, BPPN: Garbage In Garbage Out. Center for Banking Crisis. Jakarta

QE Journal | Vol.05 - No. 03 September 2016 - 162 
E. Mamatzakiz, C. Staikouras dan N. Koutsomanoli-Fillipaki. 2005. Competition and Concentration in The Banking Sector of The South Eastern European Region. Emerging Market Review 6 (2005) 192209

Gujarati, Damodar N., 2003, Basic Econometric Fourth Edition. Singapore: McGraw-Hill/Irwin 436 Buletin Ekonomi Moneter dan Perbankan, April 2013

Hondroyiannis, G., Lolos S., dan Papapetrou E. 1999. Assesing Competitive Conditions in The Greek Banking System. Journal of International Financial Markets, Institutions and Money 9 (1999) 377-391.

McLeod, Ross, 1999, Control and Competition : Banking deregulation and re-gulation Indpnesia, Journal of the Asia Pasific Economy,

Mudrajad, Kuncoro. 2007. Metode Kuantitatif: Teori dan Aplikasi untuk Bisnis dan Ekonomi. Edisi Ketiga. Yogyakarta: UPP AMP YKPN.

Mulyaningsih, Tri. dan Daly, Anne. 2011. Competitive Conditions In Banking Industri: An Empirical Analysis Of The Consolidation, Competition And Concentration In The Indonesia Banking Industri Between 2001 And 2009". Bank Indonesia. Buletin Ekonomi, Moneter dan Perbankan, Oktober 2011: 151-185. 